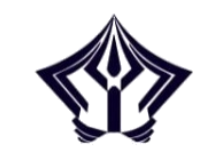

ANFUSINA: JOURNAL OF PSYCHOLOGY

http://ejournal.radenintan.ac.id/index.php/anfusina

DOI: //dx.doi.org/10.24042/ajp.v2i2.6098

Volume 2, Nomor 2, Oktober Tahun 2019

\title{
Hubungan Kebermaknaan Hidup Dan Keteraturan Melaksanakan Shalat Dengan Psychologycal Well-Being Pada Mahasiswa
}

\author{
Iin Yulianti \\ Program Studi Psikolgi Islam \\ Universitas Islam Negeri Raden Intan Lampung \\ iin_yu@yahoo.co.id \\ Regita Cahyani \\ Program Studi Psikolgi Islam \\ Universitas Islam Negeri Raden Intan Lampung \\ regitacahyani978@gmail.com
}

\begin{abstract}
Psychologycal well-being affects mental health, social functioning, interpersonal relationships, health, and adaptability. There are several factors that influence psychologycal well-being, such as meaning, purpose in life, and religiosity. The purpose of this study was to determine the relationship between the meaningfulness of life and the regularity of praying with psychologycal well-being in the 2016 class year students at the Faculty of Usuluddin and Religious Studies of UIN Raden Intan Lampung. The hypothesis proposed in this study is that there is a relationship between the meaningfulness of life and the regularity of praying with psychologycal well-being in students. The subjects in this study were students in 2016 at the Faculty of Islamic Studies and Religious Studies of UIN Raden Intan Lampung totaling 70 people taken by propotionate random sampling technique. Data collection methods in this study used three psychological scales namely the psychological well-being scale with 33 items $(\alpha=0.889)$, the scale of meaningfulness of life with 25 items $(\alpha=0.843)$ and the regular scale for praying with 49 items $(\alpha$ $=0.958)$. The data that has been collected is then analyzed using
\end{abstract}


multiple regression analysis techniques assisted by the SPSS 21.0 for Windows program. The results showed that Rxl.2y $=0.530$ with a value of $F=13.082$ with $p=0.000$ ( $p$ <0.01) which means the hypothesis is accepted that there is a significant positive relationship between the meaningfulness of life and the regularity of prayer with psychologycal well-being in students with $R 2=0.281$. The ability of life and regular prayers contributed $28.1 \%$ to psychologycal wellbeing. The second result with rxly $=0.302$ with $p=0.011(p<0.05)$ which showed a significant positive relationship between meaningfulness of life with psychologycal well-being in the 2016 class year students at the Faculty of Usuluddin and Religious Studies of UIN Raden Intan Lampung. The third result with rx $2 y=$ 0.518 with $p=0,000(p<0.05)$ which shows a significant positive relationship between the regularity of prayer and psychologycal well-being in students.

\begin{abstract}
Abstrak
Kesejahteraan psikologis berdampak terhadap kesehatan mental, fungsi sosial, hubungan interpersonal, kesehatan, dan kemampuan penyesuaian. Ada beberapa faktor yang meningkatkan kesejahteraan psikologis, seperti makna, tujuan hidup, dan religiusitas. Tujuan penelitian ini untuk mempelajari hubungan antara kebermaknaan hidup dan keteraturan melaksanakan shalat dengan kesejahteraan psikologis pada mahasiswa angkatan 2016 di Fakultas Ushuluddin dan Studi Agama UIN Raden Intan Lampung. Hipotesis yang diajukan pada penelitian ini adalah ada hubungan antara kebermaknaan hidup dan keteraturan melaksanakan shalat dengan kesejahteraan psikologis pada mahasiswa. Subjek pada penelitian ini adalah mahasiswa angkatan 2016 di Fakultas Ushuluddin dan Studi Agama UIN Raden Intan Lampung yang mengumpulkan 70 orang yang diambil dengan teknik propotionate random sampling. Metode pengumpulan data pada penelitian ini menggunakan skala psikologi dengan skala kesejahteraan psikologis dengan 33 aitem $(\alpha=0,889)$, skala kebermaknaan hidup dengan 25 aitem $(\alpha=0,843)$ dan skala keteraturan pelaksanaan shalat dengan 49 aitem $(\alpha=0,958)$. Data yang telah terkumpul kemudian dianalisis dengan menggunakan analisis regresi berganda yang dikirimkan dengan program SPSS 21.0 untuk Windows. Hasil penelitian menunjukkan $\mathrm{Rx} 1.2 \mathrm{y}=0,530$ dengan nilai $F=13,082$ dengan $p=0,000(p<0,01)$ yang berarti hipotesis yang diterima antara ada hubungan yang positif signifikan antara kebermaknaan hidup dan keteraturan terkait shalat dengan kesejahteraan psikologis pada mahasiswa dengan $\mathrm{R} 2=0,281$. Kebermakaan hidup dan keteraturan melaksanakan shalat memberikan kontribusi efektif $28,1 \%$ terhadap kesejahteraan psikologis. Hasil kedua dengan $\mathrm{rx} 1 \mathrm{y}=0,302$ dengan $\mathrm{p}=0,011$ ( $\mathrm{p}$ $<0,05$ ) yang menunjukkan adanya hubungan positif signifikan antara
\end{abstract}


kebermaknaan hidup dengan kesejahteraan psikologis pada mahasiswa angkatan 2016 di Fakultas Ushuluddin dan Studi Agama UIN Raden Intan Lampung. Hasil tiga dengan rx $2 y=0,518$ dengan $\mathrm{p}=0,000(\mathrm{p}<0,05)$ yang menunjukkan hubungan positif signifikan antara keteraturan hubungan shalat dengan kesejahteraan psikologis pada mahasiswa.

Keywords: Meaning of Life, Regularity of Performing Shalat, Psychological Well-Being

\section{Pendahuluan}

Menurut peraturan pemerintah RI No. 30 tahun 1990 mahasiswa adalah peserta didik yang terdaftar dan belajar di perguruan tinggi tertentu. Perguruan tinggi diharapkan mampu memberikan pengalaman terbaik bagi mahasiswa sehingga membuat mahasiswanya merasa sejahtera secara fisik maupun psikologis (psychologyal well-being) karena kesejahteraan mahasiswa mempengaruhi hampir seluruh aspek bagi optimalisasi fungsi mahasiswa di kampus (Smit, 2010).

Perasaan sejahtera secara psikologis menjadi salah satu hal yang memberikan dampak perasaan bahagia dan puas menjalani hidup dalam diri seseorang mahasiswa. Psychologycal well-being terdiri dari kepuasan hidup dan juga perasaan yang positif seperti rasa senang, gembira dan puas (Headey \& Wooden, 2004)

Menjadi seseorang mahasiswa membawa suatu status baru bagi individu, di mana mahasiswa diharapkan menjadi agent of change. Status ini menjadi suatu beban dan tanggung jawab yang harus diemban individu, terlepas dari tugas dan kewajibaanya menjadi seorang mahasiswa sesuai dengan peraturan yang berlaku ditempatnya menimba ilmu. Hal ini diungkapkan oleh Direktorat Jenderal Pendidikan Tinggi (2012) bahwa lulusan perguruan tinggi diharapkan menjadi pribadi yang memiliki kualitas penguasaan ilmu pengetahuan dan teknologi yang tinggi, didukung dengan kemampuan softskill yang memadai.

Namun pada kenyataanya tugas dan tanggung jawab ini mempengaruhi kondisi psychologycal well-being mahasiwa. Penelitian Nugraheni (2012) terhadap mahasiswa Universitas Gadjah Mada menunjukkan bahwa 31,8\% mahasiswa tahun pertama memiliki tingkat psychologycal well-being yang sedang, dan $22,7 \%$ memiliki psychologycal well-being yang rendah. 
Psychologycal well-being mengacu pada pengalaman dan fungsi psikologis yang optimal yang meliputi fungsi dari otonomi diri, penguasaan lingkungan, pertumbuhan pribadi, hubungan positif dengan orang lain, tujuan hidup dan penerimaan (Ryff, 1989). Psychologycal well-being tidak didapat begitu saja dalam hidup, tetapi didapat dari bagaimana individu itu sendiri melakukan berbagai hal untuk mendapatkannya. Psychologycal well-being dipengaruhi oleh beberapa faktor diantaranya kepribadian, makna dan tujuan hidup, agama/kepercayan (religiusitas) (Argyle, 2001).

Berdasarkan faktor yang mempengaruhi psychologycal wellbeing, diduga kebermaknaan hidup merupakan salah satu faktor yang mempengaruhi psychologycal well-being. Ryff (1989) menyatakan bahwa keberadaan makna hidup memiliki peran penting dalam tercapainya psychologycal well-being. Hal penting dalam hidup bermakna adalah memiliki tujuan hidup yang jelas, baik jangka pendek maupun jangka panjang. Bila kebermaknaan hidup ditemukan dan tujuan hidup ditetapkan dan berhasil direalisasikan, maka kehidupan akan terasa sangat berarti (meaningfull) sehingga pada akhirnya menimbulkan kebahagiaan (happiness) yang dapat mengacu pada kesejahteraan psikologis seseorang (Frankl, 2003).

Selain kebermaknaan hidup sebagai faktor psychologycal wellbeing, terdapat juga bahwa religiusitas merupakan salah satu faktor yang mempengaruhi psychologycal well-being. Menurut Susilaningsih (dalam Okdinata, 2009) religiusitas atau keberagamaan adalah kristal-kristal nilai agama dalam diri manusia yang terbentuk melalui proses internalisasi nilai-nilai agama semenjak usia dini. Religiusitas akan terbentuk menjadi nilai pada akhir usia anak dan berfungsi pada awal remaja. Kristal nilai yang terbentuk akan berfungsi menjadi pengarah sikap dan perilaku dalam kehidupannya. Menurut Najati (2005) kehidupan religius atau keagamaan dapat membantu manusia dalam menurunkan kegelisahan, ketegangan, dan kecemasan. Salah satu upaya yang dilakukan untuk menunjang psychologycal well-being adalah dengan ibadah yaitu keteraturanan dalam melaksankan shalat.

Berdasarkan uraian diatas, kebermaknaan hidup dan keteraturan melaksanakan shalat sangat dibutuhkan oleh mahasiswa dalam meningkatkan psychologycal well-being. Sebelumnya terdapat penelitian yang dilakukan oleh Hiborang (2014) dengan judul hubungan kebermaknaan hidup dengan pada siswa SMA di Mahera Utara dengan jumlah subjek 70 siswa. Yang menunjukkan bahwa terdapat hubungan yang positif dan siginifikan antara kebermaknaan 
hidup dengan psychologycal well-being. Yang membedakan penelitian ini dengan penelitian tersebut adalah masalah yang melatar belakangi, kemudian terdapat tiga variabel yang diteliti berbeda dengan penelitian sebelumnya yang hanya terdapat dua variabel saja dan hal yang terakhir yang membedakan yaitu lokasi penelitian ini yaitu mahasiswa UIN Raden Intan Lampung.

Ryff (1989) mengungkapkan bahwa psychological well-being sebagai suatu kondisi dimana seorang individu memiliki tujuan dalam hidupnya agar lebih bermakna, menyadari potensi-potensi yang dimiliki, menciptakan dan mengatur kualitas hubungannya dengan orang lain, sejauh mana mereka merasa bertanggung jawab atas kehidupannya sendiri, serta berusaha mengembangkan dan mengeksplorasi dirinya.

Diungkapkan oleh Ryff (1989), bahwa psychological wellbeing tidak hanya terdiri dari efek positif, efek negatif, dan kepuasan hidup, melainkan paling baik dipahami sebagai sebuah konstruk multidimensional yang terdiri dari sikap hidup. Ryff (1989) membuat skala dari psychological well-being berdasarkan pada sebuah integrasi dari kesehatan mental, klinis, dan teori perkembangan rentang kehidupan. Dimensi ini di asumsikan untuk mengukur semua aspek dari psychologycal well-being dan melibatkan penerimaan diri (self-acceptance), hubungan positif dengan orang lain (positive relation with other), otonomi (autonomy), penguasaan lingkungan (enviromental mastery), tujuan hidup (purpose in life), dan perkembangan diri (personal growth).

Menurut Frankl (2004), makna hidup merupakan sesuatu yang dianggap penting, benar dan didambakan serta memberikan nilai khusus bagi seseorang. Makna hidup juga bersifat personal dan unik. Ini disebabkan karena individu bebas menentukan caranya sendiri dalam menemukan dan menciptakan makna. Sehingga penemuan dan penciptaan makna hidup menjadi tanggung jawab individu itu sendiri dan tidak dapat diserahkan kepada orang lain, karena hanya individu itu sendirilah yang mampu merasakan dan mengalami makna hidupnya.

Menurut Ancok (Bukhori, 2012) kehidupan bermakna akan dimiliki sesorang apabila dia mengetahui apa makna dari sebuah pilihan hidupnya. Makna hidup (Budiharjo, 1997) adalah hal-hal yang memberikan arti khusus bagi seseorang apabila berhasil dipenuhi akan menyebabkan kehidupannya dirasakan berarti dan berharga, sehingga akan menimbulkan penghayatan kehidupan. Paloutzain (Sumanto, 2006) yang mengemukakan bahwa perasaan keagamaan 
yang matang akan membantu individu memuaskan "keinginan akan makna" dengan mengambil ajaran agama yang diterapkan dalam seluruh aspek kehidupannya.

Shalat merupakan kewajiban yang dilakukan umat muslim setiap hari minimal lima waktu sehari sebagai wujud rasa syukur dan keimanan kita kepada Allah SWT. Saat melaksanakan shalat, seluruh aspek kesehatan (lahir, mental dan pikir) bersinergi secara harmonis. Motivasi meneggakan shalat bersumber pada kesadaran diri (aspek mental, spritual dan pikir) untuk menghambakan kepada Allah SWT sebagai sang khalik. Kemudian dilanjutkan dengan rukun atau tata gerakan shalat itu sendiri (Wratsangko, 2006).

Menurut Rahman (2002) shalat berarti doa, ibadah, memohon dengan khusyuk kepada Tuhan, meminta rahmat Tuhan. Hasan (2002) menjelaskan bahwa shalat menurut bahasa (etimologi) adalah doa, sedangkan shalat menurut istilah (terminologi) adalah semua ucapan dan perbuatan yang bersifat khusus yang dimulai dengan takbir dan disudahi dengan salam, dan memenuhi beberapa syarat yang ditentukan. Berdasarkan latar belakang masalah yang telah di uraikan, maka rumusan masalah dalam penelitian ini apakah ada hubungan antara kebermaknaan hidup dan keteraturan melaksanakan shalat dengan psychologycal well-being pada mahasiswa?

\section{Metode Penelitian}

Penelitian ini merupakan penelitian kuantitatif dengan menggunakan teknik analisis regresi berganda. Populasi dalam penelitian ini adalah mahasiswa Fakultas Ushuluddin dan Studi Agama UIN Raden Intan Lampung angkatan 2016 yang berjumlah 70 orang. Sampel yang digunakan dalam penelitian ini menggunakan teknik sampling propotionate random sampling.

Teknik pengumpulan data yang digunakan dalam penelitian ini adalah dengan menggunakan skala. Skala dalam penelitian ini akan diberikan kepada responden dengan menggunakan skala likert dengan klasifikasi: 1. Sangat Sesuai (SS), 2. Sesuai (S), 3. Tidak Sesui (TS), 4. Sangat Tidak Sesuai (STS). Terdapat tiga skala dalam penelitian ini, yaitu skala psychologycal well-being, kebermaknaan hidup dan keteraturan melaksanakan shalat. psychologycal well-being diukur dengan skala psychologycal wellbeing yang merupakan skala adaptasi dari Yanti Langi (2019) yang akan diungkap berdasarkan aspek-aspek psychologycal well-being menurut Ryff (1989) yaitu penerimaan diri, otonomi, hubungan 
yang positif dengan orang lain, pertumbuhan pribadi, penguasaan lingkungan dan tujuan hidup. Jumlah aitem valid yaitu 33 dari 50 aitem. Kebermaknaan hidup diukur menggunakan skala kebermaknaan hidup. Skala ini merupakan skala adaptasi dari Izzati (2016) yang digunakan untuk mengungkap kebermaknaan hidup yang dimiliki individu menurut Craumbagh dan Maholick (Prawira, 2010) yaitu: memiliki tujuan yang jelas, memiliki perasaan bahagia, memiliki tanggung jawab, memiliki alasan keberadaan (eksistensi), memiliki kontrol diri, dan tidak merasa cemas akan kematian. Jumlah aitem valid yaitu 25 dari 40 aitem. Selanjutnya keteraturan melaksanakan shalat diukur menggunakan skala keteraturan melaksanakan shalat. Skala ini merupakan skala adaptasi dari Ikhwanisifa (2008) yang akan diungkap berdasarkan aspek aspek keteraturan melaksanakan shalat menurut Adi (1994) yaitu: ketepatan dan disiplin, kesadaran dan tanggung jawab, kekuatan kehendak dan dapat mengatasi pengaruh lingkungan. Jumlah aitem valid yaitu 49 dari 53 aitem.

\section{Hasil Dan Pembahasan}

Hasil dari data skala psychologycal well-being, skala kebermaknaan hidup dan skala keteraturan melaksanakan shalat yang disebarkan pada subjek penelitian merupakan data skor yang sudah dianalisis dengan perhitungan statistik sebagaimana tertera dalam tabel berikut ini. 


\begin{tabular}{ccccccccccc}
\hline & $\sum$ & \multicolumn{4}{c}{ Skor Empirik } & \multicolumn{5}{c}{ Skor Hipotetik } \\
\cline { 3 - 10 } Variabel & Aitem & Min & Maks & Mean & SD & Min & Maks $\begin{array}{c}\text { Mean } \\
(\mu)\end{array}$ & $\begin{array}{c}\text { SD } \\
(\sigma)\end{array}$ \\
\hline $\begin{array}{r}\text { Psychologycal } \\
\text { Well-Being }\end{array}$ & 33 & 91 & 129 & 110,13 & 8,346 & 91 & 132 & 111,5 & 6,8 \\
$\begin{array}{r}\text { Kebermaknaan } \\
\text { Hidup }\end{array}$ & 25 & 71 & 97 & 84,69 & 6,045 & 71 & 100 & 85,5 & 4,8 \\
$\begin{array}{r}\text { Keteraturan } \\
\text { Melaksanakan } \\
\text { Shalat }\end{array}$ & 49 & 140 & 196 & 164,30 & 12,685 & 49 & 196 & 122,5 & 24,5 \\
\hline
\end{tabular}

Analisis yang dilakukan menggunakan teknik analisis regresi berganda dengan bantuan program SPSS 22.0 for windows. Berikut hasil analisis yang telah dilakukan :

1. Hasil analisis data memperoleh nilai koefisien korelasi Rx1.2-y= 0,530 dengan nilai $F=13,082$ dengan $p=0,000$ $(\mathrm{p}<0,01)$ yang berarti bahwa ada hubungan antara kebermaknaan hidup dan keteraturan melaksanakan shalat dengan psychologycal well-being pada mahasiswa angkatan 2016 di Fakultas Ushuluddin dan Studi Agama UIN Raden Intan Lampung.

2. Hasil kedua dengan $\mathrm{rx}_{1} \mathrm{y}=0,302$ dan $\mathrm{p}=0,011 \quad(\mathrm{p}<0,05)$, yang menunjukkan ada hubungan positif signifikan antara kebermaknaan hidup dengan psychologycal wellbeing pada mahasiswa angkatan 2016 di Fakultas Ushuluddin dan Studi Agama UIN Raden Intan Lampung. Semakin tinggi kebermaknaan hidup pada mahasiswa, maka semakin tinggi pula psychologycal well-being yang dimiliki.

3. Hasil ketiga dengan $\operatorname{rx}_{2} y=0,518$ dan $p=0,000(p<0,01)$, yang menunjukkan ada hubungan positif signifikan antara keteraturan melaksanakan shalat dengan psychologycal well-being pada mahasiswa angkatan 2016 di Fakultas Ushuluddin dan Studi Agama UIN Raden Intan Lampung. Semakin tinggi keteraturan melaksanakan shalat pada mahasiswa, maka semakin tinggi pula psychologycal well-being yang dimiliki.

Berdasarkan penelitian yang telah dilakukan, didapatkan hasil bahwa ada hubungan yang signifikan antara kebermaknaan hidup dan 
keteraturan melaksanakan shalat dengan psychologycal well-being pada mahasiswa angkatan 2016 di Fakultas Ushuluddin dan Studi Agama UIN Raden Intan Lampung dengan $\mathrm{R}=0,530$ dan $\mathrm{p}=0,000(\mathrm{p}$ $<$ 0,01). Hal tersebut menunjukkan bahwa semakin tinggi kebermakaan hidup dan keteraturan melaksanakan shalat maka semakin tinggi pula psychologycal well-being pada mahasiswa dan sebaliknya, semakin rendah kebermaknaan hidup dan keteraturan melaksanakan shalat maka semakin rendah pula psychologycal wellbeing pada mahasiswa.

Menurut Ryff (1989) psychologycal well-being merupakan suatu kondisi individu yang ditandai dengan adanya perasaan bahagia, tidak adanya gejala depresi dan memiliki kepuasan dalam hidup. Argyle (2001) menyatakan terdapat tiga faktor yang mempengaruhi psychologycal well-being yaitu kepribadian, makna dan tujuan hidup, agama/kepercayaan (religiusitas). Hasil dari penelitian ini menunjukkan arah yang sama dengan pendapat diatas, bahwa faktor kebermaknaan hidup memiliki pengaruh terhadap psychologycal well-being.

Frankl (1989) menyatakan kebermaknaan hidup adalah sebuah nilai yang memunculkan motivasi yang kuat dan mendorong seseorang untuk melakukan kegiatan yang berguna, sedangkan hidup yang berguna adalah hidup yang terus menerus memberi makna pada diri sendiri maupun orang lain. Selanjutnya selain kebermaknaan hidup, psychologycal well-being juga dipengaruhi oleh faktor religiusitas. Bastaman (2000) menyatakan bahwa religiusitas adalah hal yang berkaitan langsung antara individu dengan tuhan. Salah satu upaya yang dilakukan untuk menunjang psychologycal well-being adalah dengan ibadah yaitu keteraturan melaksanakan shalat. Hasan (2000) mengatakan salah satu hikmah shalat yaitu sebagai penenang jiwa orang resah gelisah, dan dapat menimbulkan ketenangan hati dan ketentraman batin.

Hal tersebut serupa dengan penelitian lain yang telah dilakukan oleh Hiborang (2014) tentang Hubungan Antara Kebermaknaan Hidup dengan Psychologycal Well-Being pada siswa SMA Negeri 5 Halmahera Utara. Berdasarkan hasil analisis data yang telah dilakukan terhadap kebermaknaan hidup dengan psychologycal wellbeing terdapat hasil koefisien relasi sebesar 0,512 dengan taraf signifikasi sebesar $0,000(\mathrm{p}<0,05)$.

Hasil dari penelitian ini menunjukkan arah yang sama dengan penelitian Hiborang (2014) diatas, bahwa faktor internal dan eksternal memiliki pengaruh terhadap psychologycal well-being, faktor yang 
telah diujikan pada penelitian ini adalah kebermaknaan hidup dan keteraturan melaksanakan shalat dimana keduanya memiliki pengaruh terhadap psychologycal well-being. Berdasarkan hasil analisis pada ketiga variabel, dapat diketahui jumlah sumbangan efektif dari masing-masing variabel bebas terhadap variabel terikat. Variabel kebermaknaan hidup memberikan sumbangan efektif sebesar 1,4\% dan variabel keteraturan melaksanakan shalat memberikan sumbangan efektif sebesar $14 \%$ yang berarti terdapat $28,1 \%$ kontribusi yang diberikan kedua variabel tersebut terhadap variabel psychologycal well-bing. Selebihnya, 71.9\% dipengaruhi oleh faktorfaktor lain diluar penelitian ini seperti kepribadian dan dukungan sosial.

\section{Simpulan dan Saran}

Berdasarkan penelitian yang telah dilakukan dapat disimpulkan bahwa: Ada hubungan antara kebermaknaan hidup dan keteraturan melaksanakan shalat dengan psychologycal well-being pada mahasiswa angkatan 2016 di Fakultas Ushuluddin dan Studi Agama UIN Raden Intan, ada hubungan antara kebermaknaan hidup dengan psychologycal well-being pada mahasiswa angkatan 2016 di Fakultas Ushuluddin dan Studi Agama UIN Raden Intan Lampung, ada hubungan antara keteraturan melaksanakan shalat dengan psychologycal well-being pada mahasiswa angkatan 2016 di Fakultas Ushuluddin dan Studi Agama UIN Raden Intan Lampung.

Berdasarkan hasil penelitian yang telah dilaksanakan dan kesimpulan yang telah dipaparkan di atas, maka peneliti memberikan saran kepada pihak-pihak terkait untuk kemajuan bersama, saran tersebut ditujukkan untuk:

1. Bagi mahasiwa/mahasiswi agar lebih memperhatikan, mengenali dan memamahi dirinya akan pentingnya memiliki makna hidup dan terbiasa melaksanakan shalat lima waktu sehingga mahasiswa memiliki psychologycal well-being dengan baik dalam kehidupan sehari-hari.

2. Bagi tenaga pengajar atau dosen hendaknya dapat mengidentifikasi dan mengetahui masalah-masalah yang terjadi pada mahasiswa, misalnya dengan mengadakan pelatihan regulasi diri dan efikasi diri untuk para mahasiswa sehingga mahasiswa dapat meningkatkan serta mempertahankan prestasi akademik yang telah diraih. 
3. Bagi penelitian selanjutnya yang tertarik untuk meneliti dan mengkaji kembali efikasi diri dan regulasi diri dengan prestasi akademik diharapkan dapat lebih cermat dalam pengambilan subjek penelitian. Selain itu, bagi para peneliti selanjutnya diharapkan dapat menggunakan variabel lain yang dapat mempengaruhi prestasi akademik mahasiswa seperti inteligensi, sikap belajar, bakat, minat belajar, motivasi belajar, penyesuaian diri, dan lingkungan.

\section{Referensi}

Adi, A.W. (1994). Hubungan shalat dengan kecemasan. Jakarta: Studi Press.

Argyle, M. (2001). Psychology of happines. New York: Routledge.

Ancok, J., \& Suroso, F. (2005).: Psikologi islami solusi islam atas problem-problem psikologi. Yogyakarta: Pustaka Pelajar.

Azwar, S. 2009. Realibitas dan validitas (edisi kedua). Yogyakarta: Pustaka Belajar.

Arikunto, S. (2010). Prosedur penelitian. Jakarta: Rineka Cipta.

Frankl, V.E. (2004). Man's search for meaning. Bandung: Penerbit Nuansa.

Frankl, V. E. (2003). Logoterapi: Terapi psikologi melalui pemaknaan eksistensi. Yogyakarta: Kreasi Wacana.

Hiborang, A. S.E. (2014). Hubungan antara kebermaknaan hidup dengan psycholoycal well-being (PWB) pada siswa SMA negeri 5 halmahera utara (Skripsi). Fakultas Psikologi Universitas Kristen Satya Wacana, Salatiga.

Hurlock, E. B. (1994). Psikologi perkembangan: Suatu pendekatan sepanjang rentang kehidupan. Jakarta: Erlangga.

Malay, M.N. (2019). Modul praktikum statistika: Analisis Data SPSS. Fakultas Ushuluddin dan Studi Agama UIN Raden Intan Lampung. 
Malay, M.N., Fitriani, A., \& Islamia, I. (2019). Pedoman penulisan skripsi prodi psikologi islam. Fakultas Ushuluddin dan Studi Agama UIN Raden Intan Lampung.

National Health Ministries. (2006). Stress \& the college student. USA.

Ryff, C. D dan Keyes C.L.M. 1995. The structure of psychologycal well being revisted. Journal of Personality and Social Psychology, 57.

Ryff, C. D. \& Singer, B. (2008). Know thyself and become what you are: A eudaimonic approach to psychologycal wellbeing. Journal of Happiness Studies, 9, 13-39.

Santrock, J. W. (2015). Psikologi pendidikan. (Wibowo, T., Penerj). Jakarta: Prenadamedia Group.

Sugiyono. (2013). Metode penelitian kuantitatif, kualitatif dan R\&D. Bandung: Alfabeta.

Winarsunu, T. (2015). Statistik dalam penelitian psikologi \& pendidikan. Malang: UMM Press. 